\title{
EARLY DETECTION KANKER SERVIKS SEBAGAI UPAYA PENINGKATAN DERAJAT HIDUP PEREMPUAN
}

\author{
Evicenna Naftuchah Riani¹), Dewi Ambarwati ${ }^{11}$ \\ 1)Program Studi Kebidanan Program Sarjana, Fakultas IImu Kesehatan, Universitas Muhammadiyah Purwokerto \\ Corresponding author : Evicenna Naftuchah Riani \\ E-mail: evicenna@gmail.com
}

Diterima 28 Februari 2020, Disetujui 5 April 2020

\begin{abstract}
ABSTRAK
Kanker merupakan penyebab kematian terbesar di dunia. Pada tahun 2018 terdapat 18,1 juta kasus dengan angka kematian sebesar 9,6 juta. Di Indonesia kanker serviks menduduki peringkat kedua setelah kanker payudara yang diderita oleh perempuan dengan angka kejadian 23,4/100.000 penduduk dengan rata-rata kematian sebesar 13,9/100.000 penduduk. Menurut perkiraan Kementrian Kesehatan RI saat ini, jumlah perempuan penderita baru kanker serviks berkisar 90-100 kasus per 100.000 penduduk dan setiap tahun terjadi 40 ribu kasus kanker serviks. Jawa Tengah merupakan propinsi tertinggi kedua di Indonesia dengan angka kejadaian kanker serviks sebesar 19.734 kasus. Kabupaten Banyumas tiap tahun meningkat, tahun 2010 terdapat 196 kasus, tahun 2011 terdapat 243 kasus dan pada tahun 2012 terdapat 268 kasus. Pasien yang dirawat di Rumah Sakit rata-rata sudah memasuki stadium lanjut, hanya $18,5 \%$ yang masih tahap stadium 1 . Tujuan dilakukan kegiatan ibm untuk meningkatkan pengetahuan early detection kanker serviks sebagai upaya peningkatan derajat hidup perempuan. Metode yang digunakan dengan ceramah, diskusi, tanya jawab, demonstrasi iva dan pap smear serta evaluasi kegiatan. Terdapat peningkatan pengetahuan tentang tanda gejala kanker serviks dan peningkatan kesadaran masyarakat akan pentingnya pemeriksaan IVA dan papsmear sebagai upaya peningkatan derajat hidup perempuan.
\end{abstract}

Kata kunci : early detection; kanker serviks; derajat hidup perempuan.

\begin{abstract}
Cancer is the biggest cause of death in the world. In 2018 there were 18.1 million cases with a mortality rate of 9.6 million. In Indonesia cervical cancer is ranked second after breast cancer suffered by women with an incidence of 23.4 / 100,000 population with an average death of 13.9 / 100,000 population. According to current estimates of the Indonesian Ministry of Health, the number of women with new cervical cancer ranges from 90-100 cases per 100,000 population and 40 thousand cases of cervical cancer occur annually. Central Java is the second highest province in Indonesia with a cervical cancer survival rate of 19,734 cases. Banyumas Regency has increased every year, in 2010 there were 196 cases, in 2011 there were 243 cases and in 2012 there were 268 cases. Patients treated at the hospital on average had entered an advanced stage, only $18.5 \%$ were still in stage 1 . The aim was to carry out $\mathrm{ibm}$ activities to increase knowledge of early detection of cervical cancer as an effort to increase the degree of life of women. The method used by lectures, discussions, questions and answers, demonstrations iva and pap smears and evaluation of activities. There is an increase in knowledge about the symptoms of cervical cancer and an increase in public awareness of the importance of IVA and Pap smear testing in an effort to increase the degree of life of women.
\end{abstract}

Keywords : early detection; cervical cancer; degree of life of women.

\section{PENDAHULUAN}

Kanker serviks merupakan kanker kedua yang paling banyak diderita oleh perempuan di Dunia. Berdasarkan GLOBOCAN 2012 kanker serviks menduduki urutan ke7secara global dalam segi angka kejadian (urutan ke-6 di negara kurang berkembang) dan urutan ke-8 sebagai penyebab kematian (menyumbangkan $3,2 \%$ mortalitas, sama dengan angka mortalitas akibat leukemia). Kanker serviks menduduki urutan tertinggi di negara berkembang, dan urutan ke 10 pada negara maju atau urutan ke 5 secara global.

Kasus kanker serviks di Indonesia menduduki peringkat kedua setelah kanker payudara yang diderita oleh perempuan dengan angka kejadian 23,4/100.000 penduduk dengan rata-rata kematian sebesar 13,9/100.000 penduduk. Menurut perkiraan Kementrian Kesehatan RI saat ini, jumlah 
perempuan penderita baru kanker serviks berkisar 90-100 kasus per 100.000 penduduk dan setiap tahun terjadi 40 ribu kasus kanker serviks.

Terdapat beberapa factor penyebab meningkatnya kasus kanker serviks. Salah satu penyebab terbesar kanker serviks yaitu 90\% merupakan infeksi dari Human Papiloma Virus (HPV). Dan penyebab $10 \%$ lainnya terjadi karena kebiasaan merokok, riwayat aktifitas seksual pada usia muda/ multipartner, penggunaan alat kontrasepsi pil dalam jangka panjang, melahirkan lebih dari lima kali, gangguan imunitas, serta tidak melakukan screening IVA/ papsmear secara berkala.

Kanker serviks menjadi salah sayu penyebab morbiditas dan mortalitas di dunia. Dengan meningkatnya umur harapan hidup perempuan maka akan menurunkan insident kejadian kanker serviks, dimana terdapat hubungan antara peningkatan umur dengan kejadian kanker.

Kanker serviks akan sangat mempengaruhi hidup penderita dan keluarga. Pengobatan dan perawatan penderita kanker serviks akan membutuhkan banyak biaya yang tidak sedikit. Hal ini akan mempengaruhi sector pembiayaan kesehatan oleh pemerintah.

Keterlambatan diagnose kanker serviks menjadi salah satu penyebab meningkatnya kasus kanker serviks. Kurangnya pengetahuan akan kanker servik menjdai salah satu penyebab yang mempengaruhi persepsi dan sikap masyarakat untuk melakukan deteksi dini kanker serviks.

Diharapkan dengan melakukan deteksi secara dini jika terdapat kelainan pada serviks maka akan mendapat penanganan dan pengobatan lebih dini. Sehingga dapat meningkatkan harapan hidup perempuan, yaitu sebesar $85 \%-95 \%$.

Tujuan secara umum kegiatan ini dilaksanakan sebagai upaya menurunkan angka kejadian dan angka kesakitan yang disebabkan oleh kanker serviks di masyarakat sehingga dapat meningkatkan derajat hidup perempuan. Secara khusus tujuan kegiatan ini untuk meningkatkan pengetahuan deteksi dini kanker serviks, memberikan kesadaran akan pentingnya pemeriksaan IVA papsmear pada mitra dan penyebaran leaflet tentang deteksi dini kanker serviks pada mitra.

\section{METODE}

Penerapan IbM pada kader 'Aisyiyah Sokaraja Kulon. Kegiatan ini dilaksanakan dengan metode learning by doing. Transfer kegiatan melalui penyuluhan dan pelatihan menggunakan media leaflet, power point, audio visual (video) serta demonstrasi IVA dan papsmear. Metode yang digunakan meliputi ceramah, tanya jawab, diskusi dan penayangan video serta demonstrasi IVA dan papsmear. Tahapan kegiatan dimulai dengan icebraking, pre test, penyampaian materi, demonstrasi IVA dan papsmear serta ditutup dengan post test.

Evaluasi kegiatan dilakukan untuk mengukur tingkat keberhasilan dari program yang ditawarkan, yang meliputi evaluasi pengetahuan serta pemahaman peserta/ mitra (knowledge) yang dilakukan dengan cara pre test dan post test kepada seluruh peserta yang berjumlah 25 peserta

\section{HASIL DAN PEMBAHASAN}

Kegiatan ibm dilaksanakan sesuai dengan tahapan yang terdiri dari kegiatan penyuluhan early detection kanker serviks, demonstrasi IVA dan papsmear serta evaluasi dan monitoring kegiatan.

Penyuluhan early detection kanker serviks menggunakan media berupa leaflet, penyampaian materi dalam bentuk power point dan demonstrasi pemeriksaan IVA dan papsmear.

Selama pemberian materi berlangsung, peserta aktif berpartisipasi dan bertanya hal-hal yang tidak dipahami. Diskusi dan tanya jawab didampingi oleh Tim pengabdian. Proses diskusi membahas hal yang berkaitan dengan kanker serviks. Kegiatan ini diakhiri dengan rencana tindak lanjut penyuluhan dan demonstrasi early detection kanker serviks.

Demonstrasi pemeriksaan IVA dan papsmear yang dilakukan untuk deteksi dini kanker serviks merupakan tindak lanjut dari penyuluhan yang telah dilaksanakan dengan jumlah peserta 25 peserta, terdiri dari kader Aisyiyah Sokaraja Kulon. Kegiatan demonstrasi early detection kanker serviks terdiri dari tahapan sebagai berikut:

\section{a. Pre Test}

Kegiatan ini dilaksanakan dengan tujuan untuk mengetahui kemampuan peserta sebelum mengikuti kegiatan. Peserta diberikan soal terkait kanker payudara. Alokasi waktu yang diberikan adalah 15 menit.

b. Penyampaian Materi

Materi yang disampaikan terdiri dari materi kanker serviks serta simulasi video pemeriksaan IVA dan papsmear. Alokasi waktu yang diberikan adalah 2 kali 30 menit, dilanjutkan dengan tanya jawab. 
c. Role Play \& Simulasi

Tim memberikan demonstrasi teknik pemeriksaan IVA dan papsmear untuk mendeteksi kanker serviks. Peserta sangat antusias memperhatikan demonstrasi pemeriksaan IVA dan papsmear.

d. Post Test

Post test dilaksanakan di akhir kegiatan untuk mengetahui kemampuan peserta di akhir kegiatan. Hasil post test menunjukan adanya peningkatan pengetahuan peserta dengan nilai rata rata 67 menjadi 94,5 atau terjadi peningkatan sebesar $40 \%$ sebagaimana terdapat dalam matriks berikut :
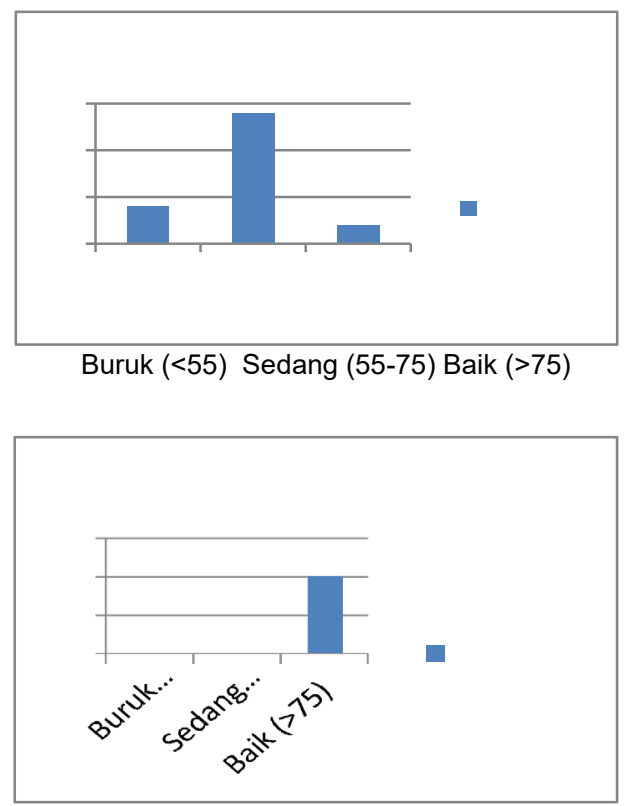

Gambar 1. Hasil Pre dan Post Test Early Detection Kanker Serviks

\section{KESIMPULAN}

Terdapat peningkatan pengetahuan kader 'Aisyiyah Sokara Kulon Kabupaten Banyumas Provinsi Jawa Tengah dalam deteksi dini, pencegahan dan penatalaksanaan kanker payudara serta terdapat peningkatan kesadaran dalam pemeriksaan IVA dan papsmear.

\section{DAFTAR RUJUKAN}

Dinas Kesehatan Kabupaten Banyumas. (2018). Profil Kesehatan.

Hakimi, M. (2014). Keadaaan Darurat Ginekologi Umum. Yogyakarta: Yayasan Essentia Medika.

Khosidah A, Trisnawati, Y. (2015). Faktor Faktor Yang Mempengaruhi Ibu Rumah Tangga Dalam Melakukan Tes IVA Sebagai Upaya Deteksi Dini Kanker Serviks.
Kementrian Kesehatan, RI. (2015). Situasi Penyakit Kanker.

Kementrian Kesehatan, RI. (2018). Panduan pelaksanaan hari kanker sedunia 2018.

Kementerian Kesehatan, RI. (2017). Panduan Penatalaksanaan Kanker Serviks.

Prawirohardjo, S. (2014). IImu Kebidanan. Jakarta: Yayasan Bina Pustaka Sarwono Prawirohardjo.

Ratnasari D, Kartika SD. (2015). Hubungan Antara Pengetahuan Mengenai Kanker Serviks Terhadap Keikutsertaan Pada Program Deteksi Dini Kanker Serviks Di Kecamatan Cilongok Kabupaten Banyumas.

Rasjidi I. (2009). Epidemiologi Kanker Serviks. Varney H, Kriebs JM, Gegor CL. (2010). Buku Ajar Asuhan Kebidanan. Volume 2. Jakarta: EGC 